\title{
PENINGKATKAN KETUNTASAN DAN \\ MOTIVASI BELAJAR FISIKA SISWA KELAS XB \\ SEMESTER I SMA NEGERI I GUBUG \\ MENGGUNAKAN MODUL PEMBELAJARAN \\ PADA POKOK BAHASAN GERAK LURUS \\ TAHUN PELAJARAN 2013 / 2014
}

\author{
Denny Rachmadi
}

\begin{abstract}
Abstrak
Dari data hasil belajar Fisika Pokok Bahasan Besaran dan Satuan nilai ratarata siswa kelas XB SMA Negeri I Gubug tahun pelajaran 2013/2014 masih di bawah 6,0. Ini menunjukkan masih rendahnya ketuntasan belajar siswa kelas XB SMA Negeri I Gubug tahun pelajaran 2013/2014 Kabu- paten Grobogan tahun pelajaran 2013/2014 dimana KKM yang ditetapkan oleh Sekolah adalah 75. Proses pembelajaran dalam penelitian ini mengu- nakan modul pembelajaran fisika.Obyek penelitian ini adalah siswa kelas XB SMA Negeri I Gubug Kabupaten Grobogan tahun pelajaran 2013/2014. Data penelitian dianalisis secara teknik diskriptip. Dari analisis data penelitian menunjukkan bahwa motivasi belajar mengalami peningkatan dibanding sebelum menggunakan modul pembelajaran. Begitu juga un- tuk hasil belajar afektif, kognitif dan psikomotor mengalami peningkatan dalam tiap siklusnya.
\end{abstract}

Kata Kunci : Modul Pembelajaran Fisika. Ketuntasan Belajar dan Motivasi Belajar

\section{PENDAHULUAN}

Dalam dunia pendidikan, guru merupakan faktor penentu un- tuk mewujudkan keberhasilan kegiatan belajar/mengajar (KBM). Hal ini menuntut Guru selalu inovatif dalam menciptakan kegiatan belajar mengajar, agar siswa dapat mencapai hasil belajar sesuai di- harapkan. Namun kenyataannya untuk mencapai itu tidaklah mu- dah. Hal ini dapat dilihat secara mikro pada siswa kelas XB SMA Negeri I Gubug Kabupaten Grobogan tahun 2013/2014 pada po- kok bahasan besaran dan sistem satuan tak dapat mencapai target ketuntasan belajar fisika. Dari hasil pengamatan dilapangan pada siswa kelas XB SMA Negeri I Gubug Kabupaten Grobogan tahun 
2013/2014 menunjukkan : evaluasi hasil belajar fisika yang diraih- nya rata-rata masih di bawah 60 , tidak semua siswa memiliki sum- ber belajar, banyaknya waktu belajar di sekolah berkurang karena adanya kegiatan agustusan sehinggga pembelajaran menjadi tidak efektif dan selama bulan puasa Ramadlon jam pelajaran di persing- kat, serta kurangnya perhatian dan keseriusan siswa dalam mengi- kuti proses belajar mengajar fisika.

Pembelajaran modul menurut Nasution (2000 : 205) merupakan usaha pembelajaran individu yang memungkinkan peserta didik menguasai suatu unit pelajaran yang dapat dilakukan setiap waktu sesuai dengan kemampuannya. Dalam modul pembelajaran berisi; petunjuk pelaksanaan, tujuan pengajaran, materi pelajaran, dan alat evaluasi serta adanya batasan ketuntasan yang harus dikuasai oleh siswa.

Dengan pembelajaran modul tersebut diharapkan masalah- masalah tentang banyaknya waktu belajar disekolah yang hilang, banyak siswa yang tidak mempunyai sumber belajar dapat teratasi. Saat siswa diberi modul berarti siswa sudah menerima materi pe- lajaran sehingga siswa dapat mempelajari semua isi modul setiap waktu dan dimana saja.

Untuk meningkatkan ketuntasan dan motivasi belajar siswa ke- las XB SMA Negeri I Gubug Kabupaten Grobogan pada semester I tahun ajaran 2013/2014, peneliti tertarik untuk menerapkan pembe- lajaran modul materi gerak lurus.

Tujuan penelitian ini adalah meningkatan ketuntasan dan motivasi belajar pada materi gerak lurus siswa kelas XB SMA Negeri I Gubug semester 1 tahun pelajaran 2013/2014.

\section{LANDASAN TEORETIS}

\section{Modul Pembelajaran}

Modul merupakan suatu paket bahan pelajaran yang memuat diskripsi tentang tujuan pelajaran yang khas, lembar petujuk guru yang menjelaskan cara mengajar yang efisien, bahan bacaan bagi siswa, lembar kunci jawaban, dan alat evaluasi.

Maksud dan tujuan digunakannya modul di dalam proses be- lajar mengajar ialah agar : tujuan pengajaran dapat dicapai secara ef- esien dan efektif, murid dapat megikuti program pendidikan sesuai dengan kecepatan dan kemampuan sendiri, murid dapat sebanyak mungkin menghayati dan melakukan kegiatan belajar sendiri baik di bawah bimbingan maupun tanpa bimbingan guru berkelanjutan. murid dapat menilai dan mengetahui hasil belajarnya sendiri,murid benar-benar 
menjadi titik pusat kegiatan belajar mengajar, kema- juan siswa diketahui dengan frekuensi yang lebih tinggi melalui evaluasi yang dilakukan pada setiap modul akhir, modul disusun dengan berdasarkan kepada konsep belajar tuntas, suatu konsep yang menekankan bahwa murid harus secara optimal menguasai pelajaran yang disajikan dalam modul itu.

Ciri-ciri pengajaran modul adalah sebagai berikut : modul meru- pakan paket pengajaan yang bersifat self-instructional, pengakuan atas perbedaan individual, memuat rumusan tujuan pembelajaran secara eksplisit, adanya asosiasi, struktur dan urutan pengetahuan, penggunaan berbagai macam media (multimedia), partisipasi aktif siswa, adanya reinforcement langsung tehadap respons siswa, ad- anya evaluasi terhadap penguasaan siswa atas hasil belajarnya.

Menurut Winkel (1996 : 424) komponen-komponen modul adalah sebagai berikut : Lembar petunjuk untuk guru (lembar- lembar ini memuat peranan guru dalam kegiatan belajar menga- jar, mendiskripsikan unit-unit yang dipelajari, kegiatan-kegiatan siswa, alatalat pelajaran yang digunakan, dan alat evaluasi), Lem- bar kegiatan siswa (lembar ini memuat keterangan-keterangan sep- erti yang tercantum dalam lembar petunjuk guru, kegiatan belajar dan tugas-tugas yang harus dikerjakan siswa dan pada lembaran ini materi pelajaran sudah diuraikan secara detail dengan kata-kata yang sederhana dan komunikatif, serta disusun secara teratur lang- kah demi langkah dalam urutan yang sistematis dan logis), Lembar kerja siswa (lembar ini memuat pengisian lembar kerja, ruangan di mana siswa dapat menulis jawaban soal atau tugas yang tercantum dalam lembar kegiatan siswa dan pada lembar ini berfungsi untk mengevaluasi apakah siswa sudah memahami materi pelajaran atau belum), Kunci Lembar Kerja Siswa (lembar ini berisi kunci jawaban atas tugas-tugas yang dicantumkan dalam kegiatan siswa, dengan disertai keterangan secukupnya dengan demikian terjadi konfirmasi dengan segera atas jawaban yang benar, dan koreksi dengan segera pula atas jawaban-jawaban yang salah), Lembar Evaluasi (lembar evaluasi ini berisi butir-butir evaluasi seperti petunjuk pengerjaan- nya dan lembaran ini merupakan berkas terpisah, dan diberikan ke- pada siswa setelah mampu menyelesaikan lembar kerjanya dengan benar), Kunci Lembar Evaluasi (lembaran ini merupakan lampiran yang berisi tes dan pedoman penilaian dan maksud diberikannya kunci lembar evaluasi adalah sebagai alat koreksi sendiri terhadap penilaian yang dilaksanakan). 
Peranan Guru dalam Pembelajaran Modul adalah sebagai Katalisator (artinya memberikan petunjuk terhadap hal-hal yang harus dipelajari siswa sehingga menimbulkan kegiatan belajar bagi siswa secara aktif), Motivator (artinya guru memberikan motivasi agar siswa meningkatkan kegiatan dalam belajar untuk mendapat- kan hasil belajar yang maksimal, yaitu mendorong siswa untuk mengembangkan inisiatif dalam memahami materi yang dipelajari), Konselor (artinya guru memberikan bimbingan kepada siswa yang mengalami masalah dalam belajar), Fasilitator (artinya guru mem- berikan kemudahan kepada siswa dalam belajar, menyuruh siswa belajar yang baik, menunjukkan sumber-sumber yang digunakan), Tutor (artinya guru dapat memberikan informasi-informasi yang dibutuhkan oleh siswa, bilamana siswa benar-benar mengalami ke- sulitan dalam mempelajari modul dan sebagai tutor guru melayani siswa bila memang diminta oleh siswa).

Penggunaan bentuk kegiatan pembelajaran modul ini menurut Nasution (2000: 206) mempunyai beberapa keuntungan sebagai berikut : 1 . Keun- tungan bagi siswa yaitu : a.Modul memberikan feedback yang banyak dan segera sehingga siswa dapat mengetahui taraf hasil belaja- rnya. Sehingga pesera didik mendapat umpan balik secara teratur dalam proses belajarnya, karena telah terintegrasi dalam bahan be- lajar yang dipelajarinya. Kesalahan dapat diperbaiki dan tidak dibi- arkan begitu saja seperti halnya dengan pengajaran konvensional. Ulangan sering hanya diberikan beberapa kali dalam semester., b.Modul disusun sedemikian rupa sehingga tujuannya jelas, spesi- fik dan dapat dicapai oleh siswa. Dengan tujuan yang jelas usaha siswa terarah untuk mencapainya dengan segera., c. pembelajaran yang membimbing siswa untuk mencapai sukses melalui lang- kah-langkah yang teratur tentu akan menimbulkan motivasi yang kuat untuk berusaha segiat-giatnya., d. pembelajaran modul dapat disesuaikan dengan perbedaan siswa antara lain mengenai kecepatan belajar, cara belajar, dan bahan pelajaran., e. pembelajaran mod- ul dengan sengaja memberi kesempatan untuk pelajaran remedial yakni memperbaiki kelemahan, kesalahan atau kekurangan siswa yang segera dapat ditemukan sendiri oleh siswa berdasarkan evalu- asi yang diberikan secara kontinyu. Siswa tak perlu mengulangi pe- lajaran itu seluruhnya akan tetapi hanya yang berkenaan dengan kekurangannya itu., 2 . Keuntungan bagi tenaga pengajar, yaitu : a.modul disusun cermat sehingga memudahkan siswa belajar untuk menguasai bahan pelajaran menurut metode yang sesuai bagi siswa yang berbeda-beda. Maka hasil belajar yang baik bag semua siswa lebih terjamin. Hal ini akan memberi rasa kepuasan yang lebih besar kepada guru., b. pembelajaran modul memberi 
kesempatan yang lebih besar dan waktu yang lebih banyak kepada guru untuk mem- berikan bantuan dan perhatian individual kepada setiap siswa yag membutuhkan, tanpa mengganggu atau melibatkan seluruh kelas., c. guru juga mendapat waktu yang lebih banyak untuk memberikan ceramah atau pelajaran tambahan sebagai pengayaan.

Menurut Nasution (2000: 218) bentuk pembelajaran modul mempunyai kekurangan-kekurangan sebagai berikut: biaya pengembangan bahan pembelajaran (modul) tinggi, menuntut disiplin belajar yang tinggi yang mungkin kurang dimiliki oleh peserta didik pada umumnya belum matang.

Untuk mengatasi hal ini, disarankan dalam penulisan modul dibuat dengan spasi satu, dicetak dengan kertas buram (yang mu- rah) dan dibutuhkan ketekunan yang tinggi dari guru (fasilitator) untuk terus memantau proses belajar peserta didik, memberi mo- tivasi dan konsultasi secara individual setiap waktu peserta didik yang membutuhkan.

\section{Motivasi Belajar}

Motivasi belajar didefinisikan oleh Thomas L. Gora dan Brophy dalam Elida Prayitno (1984 : 8) adalah energi penggerak, pengarah, dan memperkuat tingkah seseorang. Selain itu menurut Suryabrata (1991 : 70), motivasi adalah keadaan dalam pribadi seseorang yang mendorong individu untuk melakukan aktivitas-aktivitas tertentu guna mencapai tujuan.

Dari pernyataan diatas dapat disimpulkan pengertian motivasi belajar adalah kondisi psikologi yang dapat mendorong seseorang untuk melakukan interaksi aktif yang menghasilkan perubahan tingkah laku (pengetahuan, pemahaman, ketrampilan, dan sikap).

\section{Ketuntasan Belajar Fisika}

Menurut Winkel (1996 : 423) seorang murid tidak diperbole- hkan mengikuti program berikutnya sebelum ia menguasai paling sedikit $75 \%$ dari hasil bahan tersebut.

Dalam modul pembelajaran sudah tercantum sejauh mana ba- tas ketuntasan yang harus dicapai oleh siswa dalam mempelajari isi materi dalam modul. Batas ketuntasan di sesuaikan dengan hasil rapat dewan guru di SMA Negeri I Gubug yaitu dengan nilai sebe- sar 75 dari $80 \%$ siswa yang ada dalam kelas. Materi pelajaran yang tercantum dalam modul pembelajaraan ini adalah materi pelajaran fisika kelas XB SMA 
semester I pokok bahasan gerak lurus berdasarkan kurikulum tingkat satuan pelajaran SMA Negeri 1 Gubug tahun 2013/2014.

\section{Pengaruh Penggunaan Modul Pembelajaran Fisika terhadap Mo- tivasi dan Ketuntasan Belajar}

Dengan pembelajaran modul siswa diberi kesempatan belajar menurut irama dan kecepatannya masing-masing dan juga ha- rus diakui bahwa perbedaan-perbedaan perorangan mempunyai pengaruh penting terhadap proses belajar yaitu perbedaan dalam hal kemampuan intelektual, perbedaan dalam latar belakang aka- demik, dan perbedaan dalam gaya belajar, sehingga dengan modul siswa dpat mempelajari materi sendiri sesuai dengan waktu luang- nya. Dengan demikian seolaholah siswa tidak merasa dipaksa un- tuk belajar. Hal ini berbeda dengan pembelajaran yang dilakukan di sekolahan yang waktu tatap mukanya terbatas sehingga guru tidak dapat melayani siswa satu persatu sesuai perbedaan siswa

Dengan memberi kebebasan pada siswa untuk belajar berarti menurut keinginan siswa asal tidak menyimpang dari materi po- kok. Menurut Elida Prayitno, hal tersebut dapat meningkatkan mo- tivasi belajar siswa.

Membuat pelajaran penuh arti merupakan bentuk pembelaja- ran yang dapat memotivasi belajar siswa. Menurut Nursito (2002:

83) membuat pembelajaran penuh arti yaitu dengan mengaitkan pelajaran dengan kehidupan sehari-hari. Selain itu membuat bahan pelajaran bermakna yaitu mengaitkan bahan pelajaran dengan pen- galaman siswa. (Hamalik, 2001)

Dengan adanya kelebihan kemampuan yang dimiliki siswa harga diri siswa menjadi meningkat. Menurut Nursito (2002: 83) dengan penumbuhan harga diri ini dapat memotivasi siswa untuk belajar.

Dalam pembelajaran modul terdapat tujuan pembelajaran yang akan dicapai dan ada alat untuk mengetahui seberapa penca- paian belajar yang telah dilakukan, dengan demikian memudahkan siswa untuk mengontrol proses belajar yang siswa lakukan sendiri. Adanya tujuan tersebut akan mengarahkan siswa dalam melaku- kan kegiatan belajar. Kegiatan belajar dapat diwujudkan apabila se- seorang mempunyai motivasi belajar. Dalam kegiatan belajar, moti- vasi dapat dikatakan sebagai keseluruhan daya penggerak di dalam diri siswa yang 
menimbulkan kegiatan belajar sehingga tujuan yang dikehendaki siswa dapat tercapai.

Motivasi belajar menurut Winkel (1990 : 103) merupakan fak- tor psikis yang bersifat non intelektual. Peranannya ialah menum- buhkan gairah belajar, rasa senang dan bersemangat untuk belajar. Siswa yang bermotivasi kuat akan mempunyai banyak energi untuk melakukan kegiatan belajar, sehingga akan meningkatkan hasil be- lajar.

Sehingga siswa tertarik untuk mempelajari modul. Hal ini mem- buat siswa mempunyai banyak energi untuk melakukan kegiatan belajar, dengan demikian seluruh isi modul akan dapat dipelajari sesuai tujuan yang telah ditentukan dalam modul. Dikuasainya isi modul tersebut sesuai tujuan pembelajaran berarti ada perubahan penguasaan materi pelajaran yang diperoleh setelah proses belajar.

\section{Hipotesis Penelitian}

Pada pembelajaran fisika menggunakan modul pembelajaran dan tak menggunakan modul pembelajaran dilihat implikasinya ter- hadap motivasi belajar dan hasil belajar siswa, dapat ditarik dugaan sementara sebagai berikut : Penggunaan modul pembelajaran dapat miningkatkan motivasi dan ketuntasan belajar materi gerak lurus pada siswa kelas XB SMA N I Gubug Kabupaten Grobogan tahun pelajaran 2013/2014.

\section{METODE PENELITIAN}

Subjek yang diteliti adalah siswa kelas XB SMA Negeri I Gubug Kabupaten Grobogan tahun ajaran 2013/2014. Tempat yang akan digunakan dalam penelitian ini adalah SMA Negeri I Gubug Kabu- paten Grobogan, dengan waktu penelitian sekitar bulan September sampai Oktober 2013. Fokus penelitian yang diamati adalah moti- vasi belajar dan ketuntasan belajar siswa sebagai akibat dari peng- gunakan modul pembelajaran.

Skenario penerapan atau penggunaan modul pembelajaran dalam penelitian ini dilakukan dengan beberapa siklus sebagaima- na yang tertera berikut: 1.ProsesPenelitian Siklus I, yaitu: a. Peren- canaan Pembelajaran (i. Menyusun modul pembelajaran yang berisi petunjuk kerja, silabus, rencana pembelajaran, materi pelajaran, dan alat evaluasi, ii. Menyiapkan lembar pengamatan ketuntasan belajar dan motivasi belajar siswa), b. Tindakan Pembelajaran. (Guru membagikan modul pembelajaran kepada siswa, memberi- kan penjelasan tentang prosedur pembelajaran modul dan 
memberi penjelasan tentang materi yang sulit dipahami siswa setelah siswa mempelajarinya) , c. Observasi. (Guru mengamati dan mencatat ketuntasan dari materi pelajaran yang dipelajari dengan bantuan guru lain, mengukur motivasi belajar siswa kelas XB sebelum pembelaja- ran modul), c. Refleksi.(Guru mendiskusikan dengan guru lain satu bidang studi), I dengan memperhatikan permasalahan pada siklus I), (Siswa mempelajari modul dengan bimbingan guru saat di kelas jika mengalami kesulitan yang dijumpai saat belajar sendiri.), c.Observasi. (Guru mengamati dan mencatat ketuntasan dari ma- teri pelajaran yang dipelajari dan mengukur motivasi belajarnya.), d.Refleksi. (Berdasarkan observasi selanjutnya dilakukan diskusi temuan masalah baru dari siswa selama mempelajari modul. Pada penelitian ini siswa kelas XB semester I SMA N. I Gubug tahun pelajaran 2013/2014 setelah siklus II sudah mengalami peningkatan ketuntasan belajar fisika pokok bahasan gerak lurus dan peningka- tan motivasi belajar fisika, maka dalam penelitian ini cukup hanya

2 siklus

Adapun teknik penggumpulan data yang dilakukan ini menggunakan: a.Teknik Tes, yang terdiri dari tes objektif materi pelajaran yang diberikan kepada siswa setiap mengakhiri siklus, b. Teknik non tes, yang terdiri dari pengamatan psikomotor dilaksanakan saat siswa melaksanakan percobaan yang ada dalam modul dengan aspek-aspek psikomotor sesuai yang direncanakan dalam modul dan afektif dilakukan selama proses belajar berlangsung berdasar- kan aspek-aspek afektif sesuai yang direncanakan dalam modul serta angket motivasi belajar yang dilakukan sebelum pembelajaran modul berlangsung dan setelah pembelajaran modul selesai.

Adapun data dan informasi yang dianalisis adalah dalam ben tuk hasil tes dan angket. Untuk analisis hasil tes yang diperoleh setelah pembelajaran, dilakukan secara dikotomi, yaitu dengan memberi skor 1 jika jawaban betul dan memberi skor nol jika jawa- ban salah. Selanjutnya hasil tes tersebut dituangkan dalam bentuk tabel untuk mengetahui perkembangan dan perbandingan hasil se- tiap siklusnya mulai dari siklus I, II, dan selanjutnya.

Begitu juga untuk angket tentang motivasi belajar fisika berupa kuesioner tertutup terdiri dari butir yang bersifat positif dan butir yang bersifat negatif. Masing-masing pertanyaan dalam angket ter- diri lima alternatif jawaban. Dalam analisis deskripsi ini skor data yang diperoleh dari variabel pene- litian secara keseluruhan dideskripsikan dalam bentuk tabel distri- busi frekuensi dan persentase. 
Untuk melihat kecendrunganhasil pengukuran variabel motivasi belajar dan hasil belajar digunakan rerata ideal (Mi) dan simpangan baku ideal (sbi) sebagai kriteria. Kategori kecendrungan variabel motivasi belajar dan hasil belajar didasarkan pada kriteria penggunaan daerah kurva normal yang dibagi menjadi 5 (lima).

Dalam kaitan ini Kerlinger (1995) menegaskan bahwa dalam penggunaan praktisnya skor-skor deviasi standar besarnya antara \pm 3 sampai +3 seperti pada gambar berikut :

Tabel penentuan kecendrungan tinggi dan rendah motivasi dan hasil belajar menurut Sutrisno Hadi (1986) sebagai berikut:.

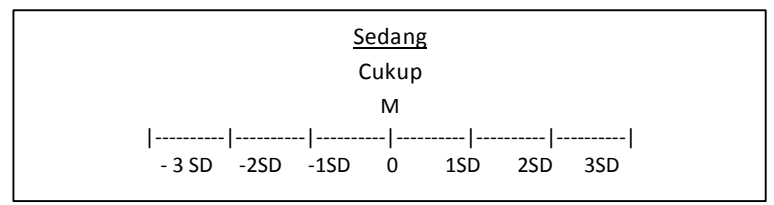

Sebagai dasar pembuatan kriteria ini adalah mean yang berada di tengah kategori cukup/sedang maka batas atas kategori tersebut menjadi $\mathrm{M}+0,6 \mathrm{SD}$ dan batas bawahnya $\mathrm{M}-0,6 \mathrm{SD}$.

Penggambaran mengenai tinggi rendahnya motivasi belajar dan hasil belajar dalam penelitian menggunakan 5 (lima) kategori, sehingga setiap unit kategori memiliki lebar kelas 6 SD dibagi rata menjadi 5 (lima) kelompok diperoleh 1,2 SD. Pembuatan jarak 1,2 SD pada pengkategorian tersebut didasarkan pada kurva normal yang secara teori memiliki 6 jarak simpangan SD.

\section{HASIL PENELITIAN DAN PEMBAHASANNYA}

\section{Hasil Penelitian}

1. Deskripsi motivasi belajar siswa terhadap mata pelajaran fisika pokok bahasan gerak lurus.

Rentang skor yang ditetapkan untuk instrumen variabel motivasi belajar siswa adalah 20 sampai 100. Berdasarkan data penelitian yang diperoleh dapat diketahui bahwa setelah pembelajaran modul, motivasi belajar siswa kelas XB SMA Negeri I Gubug meningkat dibandingkan dengan sebelum pembelajaran modul. Hal ini dapat dilihat dari skor motivasi belajar fisika, dimana setelah pembelajaran menggunakan modul skor terendah adalah 72 
dan tertinggi adalah 86 dan sebelum pembelajaran modul skor terendah adalah 53 dan skor tertinggi adalah 70 .

Penyebaran skor motivasi belajar fisika ini dapat dilihat pada tabel berikut:

Tabel distribusi frekuensi motivasi belajar fisika siswa

\begin{tabular}{|c|c|c|c|c|c|}
\hline \multirow{2}{*}{ No } & \multirow{2}{*}{ Interval } & \multicolumn{2}{c|}{ Frekuensi absolut } & \multicolumn{2}{c|}{ Frekuensi relatif \% } \\
\cline { 4 - 6 } & Siklus I & Siklus II & Siklus I & Siklus II \\
\hline 1 & $21-36$ & 0 & 0 & 0 & 0 \\
\hline 2 & $37-52$ & 0 & 0 & 0 & 0 \\
\hline 3 & $53-68$ & 0 & 28 & 0 & 97.50 \\
\hline 4 & $69-84$ & 29 & 2 & 98,75 & 2,50 \\
\hline 5 & $85-100$ & 1 & 0 & 1,25 & 0 \\
\hline
\end{tabular}

Untuk mengetahui kategori variabel motivasi belajar fisika siswa dari hasil penelitian yang telah dilakukan dapat dilihat pada tabel motivasi belajar fisika siswa berikut ini :

Tabel motivasi belajar fisika siswa

\begin{tabular}{|c|c|c|c|c|c|}
\hline \multirow{2}{*}{ Skor } & \multirow{2}{*}{ Kategori } & \multicolumn{2}{|c|}{ Frekuensi } & \multicolumn{2}{|c|}{ Frekuensi relatif } \\
\hline & & Siklus I & SiklusII & Siklus I & Siklus II \\
\hline $86,25 \mathrm{~s} / \mathrm{d} 96,87$ & Sangat tinggi & 0 & 0 & 0 & 0 \\
\hline $75,33 \mathrm{~s} / \mathrm{d} 86,25$ & Tinggi & 25 & 0 & $83,33 \%$ & 0 \\
\hline $64,41 \mathrm{~s} / \mathrm{d} 86,25$ & Cukup & 5 & 7 & $16,67 \%$ & $23,33 \%$ \\
\hline $53,49 \mathrm{~s} / \mathrm{d} 64,41$ & Rendah & 0 & 20 & 0 & $66,67 \%$ \\
\hline $42,89 \mathrm{~s} / \mathrm{d} 53,49$ & Sangat & 0 & 3 & 0 & $1,0 \%$ \\
\hline
\end{tabular}

Dari tabel motivasi belajar fisika siswa diatas dapat dilihat bahwa metode pembelajaran menggunakan modul dapat membuat motivasi belajar fisika siswa menjadi tinggi. Hal ini ditunjukkan dengan besarnya prosentase motivasi belajar 83,33 \% pada kategori tinggi. Ini berbeda dari yang dihasilkan oleh sebelum pembelajaran menggunakan modul, dimana 66,67 \% berada pada kategori rendah. Ini menunjukkan bahwa pembelajaran modul fisika dapat mempengaruhi motivasi belajar fisika siswa.

2. Deskripsi hasil belajar fisika selama pembelajaran modul pada mata pelajaran fisika pokok bahasan gerak lurus . 
Berdasarkan data penelitian yang diperoleh dapat diketahui bahwa ada peningkatan hasil belajar (afektif, kognitif, dan psikomotor)pada tiap siklusnya sebagai berikut:

Ditinjau dari nilai afektif, ada peningkatan setiap siklusnya dimana pada siklus I siswa yang mencapai nilai tertinggi hanya dalam rentang 78,72 s/d 83,01 dan rentang nilai terendah 65,83 s/d 70,12 tapi setelah siklus II mengalami peningkatan dimana nilai tertinggi nya mencapai rentang 91,62 s/d 95,91 dan rentang nilai terrendah 83,02 s/d 87,31. Dari perhitungan data nilai afektif selama pembelajaran modul diperoleh harga rerata siklus I 73,63 dan harga rerata siklus II 91,036. Ini dapat dilihat pada tabel distribusi sebagai berikut :

Tabel distribusi frekuensi hasil belajar afektif siswa

\begin{tabular}{|c|c|c|c|c|}
\hline \multirow{2}{*}{ Rentang Nilai } & \multicolumn{2}{c|}{ Frekuensi absolut } & \multicolumn{2}{c|}{ Frekuensi relatif \% } \\
\cline { 2 - 5 } & Siklus I & Siklus II & Siklus I & Siklus II \\
\hline $65,83-70,12$ & 5 & - & 16,67 & - \\
\hline $70,13-74,41$ & 12 & - & 40,00 & - \\
\hline $74,42-78,71$ & 10 & - & 33,33 & - \\
\hline $78,72-83,01$ & 3 & - & 10,00 & - \\
\hline $83,03-87,31$ & - & 5 & - & 16,67 \\
\hline $87,32-91,61$ & - & 9 & - & 30,00 \\
\hline $91,62-95,91$ & - & 16 & - & 53,33 \\
\hline
\end{tabular}

Dari tabel diatas ditunjukkan bahwa ada peningkatan jumlah siswa yang tuntas belajar dan peningkatan nilai/skor hasil belajar siswa berupa afektif. Untuk mengetahui kategori hasil belajar siswa yang diperoleh dari penelitian dapat dilihat pada tabel hasil belajar siswa berikut ini.

Tabel kecenderungan hasil belajar afektif siswa

\begin{tabular}{|c|c|c|c|c|c|}
\hline \multirow{2}{*}{ Rentang Nilai } & \multirow{2}{*}{ Kategori } & \multicolumn{2}{c|}{ Frekuensi absolut } & \multicolumn{2}{c|}{ Frekuensi relatif \% } \\
\cline { 3 - 6 } \multicolumn{2}{c|}{} & SiklusI & SiklusII & SiklusI & SiklusII \\
\hline 99,267 s/d 100 & Sangat tinggi & - & - & - & - \\
\hline 87,994 s/d 99,267 & Tinggi & - & 25 & - & 83,33 \\
\hline
\end{tabular}




\begin{tabular}{|c|c|c|c|c|c|}
\hline 76,762 s/d 87,994 & Cukup & 3 & 5 & 10 & 16,67 \\
\hline 65,445 s/d 76,762 & Rendah & 27 & - & 90 & - \\
\hline 54,176 s/d 65,445 & Sangat rendah & - & - & - & - \\
\hline
\end{tabular}

Dari tabel hasil belajar afektif siswa dapat dilihat bahwa siswa yang belajar menggunakan modul gerak lurus pada siklus II sebagian besar pada kategori tinggi sedang pada siklus I sebagian besar kategori rendah. Ini menunjukkan adanya peningkatan hasil belajar dilihat dari nilai afektif dengan demikian pembelajaran modul fisika pokok bahasan gerak lurus dapat mempengaruhi hasil belajar afektif siswa.

Ditinjau dari nilai kognitif, ada peningkatan setiap siklusnya yaitu pada siklus I siswa yang mencapai nilai tertinggi dalam rentang 76,87 s/d 84,58 dan rentang nilai terendah 46,00 s/d 53,71 tapi setelah siklus II mengalami peningkatan dimana nilai tertingginya mencapai rentang 84,58 s/d 92,30 dan rentang nilai terrendah 61,44 s/d 69,14. Dari perhitungan data nilai kognitif selama pembelajaran modul diperoleh harga rerata siklus I 68,20 dan harga rerata siklus II 78,933. Ini dapat dilihat pada tabel distribusi sebagai berikut :

Tabel distribusi frekuensi hasil belajar kognitif siswa

\begin{tabular}{|c|c|c|c|c|}
\hline \multirow{2}{*}{ Rentang Nilai } & \multicolumn{2}{c|}{ Frekuensi absolut } & \multicolumn{2}{c|}{ Frekuensi relatif \% } \\
\cline { 2 - 5 } & Siklus I & Siklus II & Siklus I & Siklus II \\
\hline $46,00-53,71$ & 2 & - & 6,67 & - \\
\hline $53,72-61,43$ & 8 & - & 26,67 & - \\
\hline $61,44-69,14$ & 11 & 3 & 36,67 & 10,00 \\
\hline $69,15-76,86$ & 7 & 13 & 23,33 & 43,33 \\
\hline $76,87-84,58$ & 2 & 11 & 6,67 & 36,67 \\
\hline $84,58-92,30$ & - & 2 & - & 6,67 \\
\hline $92,31-100$ & - & 1 & - & 3,33 \\
\hline
\end{tabular}

Dari tabel diatas ditunjukkan bahwa ada peningkatan jumlah siswa tuntas belajar dan peningkatan nilai/skor ketuntasan hasil belajar siswa berupa kognitif. Untuk mengetahui kategori hasil belajar kognitif siswa yang diperoleh dari penelitian dapat dilihat pada tabel hasil belajar siswa berikut ini. 


\section{Tabel kecenderungan hasil belajar kognitif siswa}

\begin{tabular}{|c|c|c|c|c|c|}
\hline \multirow{2}{*}{ Rentang Nilai } & \multirow{2}{*}{ Kategori } & \multicolumn{2}{c|}{ Frekuensi absolut } & \multicolumn{2}{c|}{ Frekuensi relatif $\%$} \\
\cline { 4 - 7 } & & SiklusI & SiklusII & SiklusI & SiklusII \\
\hline 88,24 s/d 100 & Sangat tinggi & - & 3 & - & 10,00 \\
\hline 78,16 s/d 88,24 & Tinggi & 2 & 11 & 2,67 & 36,67 \\
\hline 68,68 s/d 78,46 & Cukup & 18 & 13 & 60,00 & 43,33 \\
\hline 58,90 s/d 68,68 & Rendah & 8 & 3 & 26,67 & 10,00 \\
\hline 49,12 s/d 58,90 & Sangat rendah & 2 & - & 6,67 & - \\
\hline
\end{tabular}

Dari tabel hasil belajar kognitif siswa dapat dilihat bahwa siswa yang belajar menggunakan modul gerak lurus pada siklus II seba- gian besar pada kategori tinggi sedang pada siklus I sebagian besar kategori rendah. Ini menunjukkan adanya peningkatan hasil belajar dilihat dari nilai kognitif dengan demikian pembelajaran modul fisika pokok bahasan gerak lurus dapat mempengaruhi hasil belajar kognitif siswa.

3) Ditinjau dari nilai psikomotor, ada peningkatan setiap siklusnya yaitu pada siklus I siswa yang mencapai nilai tertinggi dalam rentang 81,90 s/d 85,19 dan rentang nilai terendah 72,00 s/d 75,29 tapi setelah siklus II mengalami peningkatan dimana nilai tertingginya mencapai rentang 91,80 s/d 95,00 dan rentang nilai terrendah 85,20 s/d 88,49. Dari perhitungan data nilai psikomotor selama pembelajaran modul diperoleh harga rerata siklus I sebesar 77,00 dan harga rerata siklus II sebesar 93,00. Ini dapat dilihat pada tabel distribusi sebagai berikut :

Tabel distribusi frekuensi hasil belajar psikomotor siswa

\begin{tabular}{|c|c|c|c|c|}
\hline \multicolumn{1}{c|}{} & \multicolumn{2}{c|}{ Frekuensi absolut } & \multicolumn{2}{c|}{ Frekuensi relatif \% } \\
\cline { 2 - 5 } Rentang Nilai & Siklus I & Siklus II & Siklus I & Siklus II \\
\hline $65,83-70,12$ & 5 & - & 16,67 & - \\
\hline $70,13-74,41$ & 12 & - & 40,00 & - \\
\hline $74,42-78,71$ & 10 & - & 33,33 & - \\
\hline $78,72-83,01$ & 3 & - & 10,00 & - \\
\hline $83,02-87,31$ & - & 5 & - & 16,67 \\
\hline $87,32-91,61$ & - & 9 & - & 30,00 \\
\hline
\end{tabular}




\begin{tabular}{|l|l|l|l|l|}
\hline $91,62-95,91$ & - & 16 & - & 53,33 \\
\hline
\end{tabular}

Dari tabel diatas ditunjukkan bahwa ada peningkatan jumlah siswa tuntas belajar dan peningkatan nilai/skor ketuntasan hasil belajar siswa berupa psikomotor. Untuk mengetahui kategori hasil belajar psikomotor siswa yang diperoleh dari penelitian dapat dilihat pada tabel hasil belajar psikomotor siswa berikut ini.

Tabel kecenderungan hasil belajar psikomotor siswa

\begin{tabular}{|c|c|c|c|c|c|}
\hline \multirow{2}{*}{ Rentang Nilai } & \multirow{2}{*}{ Kategori } & \multicolumn{2}{c|}{ Frekuensi absolut } & \multicolumn{2}{c|}{ Frekuensi relatif \% } \\
\cline { 3 - 6 } & & SiklusI & SiklusII & SiklusI & SiklusII \\
\hline 99,267 s/d 100 & Sangat tinggi & - & - & - & - \\
\hline 87,994 s/d 99,267 & Tinggi & - & 25 & - & 83,33 \\
\hline 76,762 s/d 87,994 & Cukup & 3 & 5 & 10 & 16,67 \\
\hline 65,445 s/d 76,762 & Rendah & 27 & - & 90 & - \\
\hline 54,176 s/d 65,445 & Sangat rendah & - & - & - & - \\
\hline
\end{tabular}

Dari tabel hasil belajar psikomotor siswa dapat dilihat bahwa siswa yang belajar menggunakan modul gerak lurus pada siklus II sebagian besar pada kategori tinggi sedang pada siklus I sebagian besar kategori rendah. Ini menunjukkan adanya peningkatan hasil belajar dilihat dari nilai psikomotor dengan demikian pembelajaran modul fisika pokok bahasan gerak lurus dapat mempengaruhi hasil belajar psikomotor siswa.

\section{Pembahasan Hasil Penelitian}

Pada penelitian ini diperoleh hasil bahwa pembelajaran modul fisika pokok bahasan gerak lurus dapat meningkatkan motivasi belajar fisika siswa siswa kelas XB SMA Negeri I Gubug tahun pelajaran 2013/2014 dilihat dari analisis motivasi belajar dimana terjadi peningkatan yang sebelum pembelajaran menggunakan modul fisika motivasi belajarnya pada kategori cukup 16,66 \% meningkat setelah pembelajaran menggunakan modul fisika yaitu pada kategori tinggi 83,33\%. 
Hal ini disebabkan dalam pembelajaran meng- gunakan modul fisika masing-masing siswa kelas XB SMA Neg- eri I Gubug tahun pelajaran 2013/2014 diberi modul pembelajaran fisika pokok bahasan gerak lurus yang didalamnya berisi silabus, rencana pembelajaran, cara dan patokan penilaian/ ketuntasan belajar, petunjuk siswa dalam belajar, dan alat untuk mengevaluasi ketuntasan belajar fisika pokok bahasan gerak lurus, sehingga siswa kelas XB SMA Negeri I Gubug tahun pelajaran 2013/2014 lebih tahu bagaimana belajar yang baik dan terarah, dapat mengevaluasi belajarnya sendiri setiap saat sehingga saat pertemuan dikelas siswa mempunyai waktu yang banyak untuk menanyakan kesulitan yang dijumpainya saat belajar sendiri dalam mempelajari gerak lurus. Dengan demikian siswa kelas XB SMA Negeri I Gubug tahun pelajaran 2013/2014 akan melihat keberartian dari konsep yang sedang dipelajari dengan demikian dapat membuat pelajaran lebih bermakna bagi siswa dan siswa merasa senang (lega). Hal ini dapat membuat siswa lebih tertarik dan terdorong untuk membaca dan mempelajari materi berikutnya, sesuai dengan yang dikemukakan oleh Nursito (2002 : 83) yaitu membuat pelajaran penuh arti dapat memotivasi belajar siswa.

Selain itu dengan pembelajaran modul dapat membantu melatih kemampuannya sendiri di rumah untuk melakukan kegiatan yang akan dilaksanakan di sekolahan, siswa dapat mengatur dan melatih dirinya sendiri agar mendapatkan hasil yang baik dalam belajar sesuai aspek - aspek yang dinilai baik afektif, kognitif, dan psikomotor, dapat membantu siswa yang belajarnya lambat sehingga dapat mengembangkan / meningkatkan kemampuannya di rumah setiap saat sesuai dengan kemampuannya (belajar kelompok dengan teman yang pandai atau yang lebih tahu.

Dengan diberi modul pembelajaran fisika siswa dapat mengerti tujuan pembelaja- ran sehuingga siswa tahu arah dalam belajar lebih terarah. Dengan demikian siswa akan termotivasi untuk belajar sesuai dengan hasil penelitian. Hal ini juga sesuai dengan pendapat Prawoto (1990 : 78) dengan mengembangkan kemampuan siswa dapat meningkatkan motivasi belajar siswa. 
Dalam pembelajaran modul, berisi petunjuk pembelajaran menggunakan modul baik untuk siswa maupun guru sehingga guru akan lebih mengontrol siswa, mengamati, memberikan bimbingan, dan memberikan penilaian / koreksi jika ada yang siswa mengalami kelemahan dalam belajar. Dengan demikian siswa tidak asal belajar dan guru juga tidak asal mengajar. Dengan tumbuhnya motivasi belajar siswa kelas XB SMA Negeri I Gubug tahun pelajaran 2013/2014 selama pembelajaran modul dapat meningkatkan ketuntasan belajarnya. Hal ini dapat dilihat adanya peningkatan ketuntasan belajar pada setiap siklus. Ini sesuai dengan yang dikemukakan oleh Winkel, dimana menurut Winkel (1990:103) menyatakan bahwa peranan motivasi belajar telah menumbuhkan gairah belajar, rasa senang dan bersemangat untuk belajar. Siswa yang bermotivasi tinggi akan mempunyai banyak energi untuk melakukan kegiatan belajar, sehingga akan meningkatkan hasil belajarnya. 


\section{PENUTUP}

\section{Simpulan}

Dari hasil penelitian yang dilakukan dapat disimpulkan sebagai berikut : 1) Motivasi belajar fisika siswa kelas XB SMA Negeri I Gubug tahun pelajaran 2013/2014 pada pembelajaran fisika menggunakan modul pembelajaran pokok bahasan gerak lurus mengalami peningkatan dari siklus I ke siklus II, yang semula siklus I tergolong kategori cukup kemudia pada siklus II berada pada kategori tinggi. Hal ini menunjukkan adanya peningkatan motivasi belajar fisika siswa kelas XB SMA Negeri I Gubug tahun pelajaran 2013/2014., 2) Ketuntasan hasil belajar fisika siswa kelas XB SMA Negeri I Gubug tahun pelajaran 2013/2014 baik afektif, kognitif, dan psikomotor mengalami peningkatan. Ini ditunjukkan dengan peningkatan ketuntasan hasil belajar dari siklus I ke siklus II.

Saran

Dari penelitian ini disarankan agar guru dan siswa dalam mempelajari fisika menggunakan modul pembelajaran. 


\section{DAFTAR PUSTAKA}

A.M. Sardiman, 2000. Interaksi dan Motivasi Belajar Mengajar. Jakarta : Rajawali Press

Azwar, S. 2001. Reliabilitas dan Validitas. Yogyakarta : Pustaka Pelajar

Dimyati dan Mudjiono. 1994. Belajar dan Pembelajaran. Jakarta : DEPDIKBUD

Hadi, Sutrisno. 1986. Statistik 2. Yogyakarta : Andi Offset

Hamalik, Oemar. 2001. Perencanaan Pengajaran Berdasarkan Pendekatan Sistem. Jakarta : Bumi Aksara

Kanginan, Martin. 1996. Fisika SMU Kelas 1. Jakarta : Erlangga

Nursito. 2002. Proses Belajar Mengajar. Jakarta : Rineka Cipta

Nasution. 2000. Pendekatan dalam Proses Belajar dan Mengajar. Bandung : Sinar Baru Algesindo

Prayitno, Elida. 1984. Interaksi dan Motivasi Belajar Mengajar. Jakarta : Gramedia

Purwanto, Ngalim. 1990. Psikologi Pendidikan. Bandung : Remaja Rosdakarya

Rinduwan. 2003. Statistika. Bandung : Alfabeta Sudjana.

1996. Metode Statistika. Bandung : Tarsito Suharsimi. 1998.

Prosedur Penelitian. Jakarta : Rineka Cipta 
2001. Dasar Evaluasi Pendidikan. Jakarta : Rineka Cipta

Suherman, E. 1990. Petunjuk Teknik untuk Melaksanakan Evaluasi Pendidikan Matematika. Bandung: Wijayakusumah

Suryabrata. 1983. Psikologi Pendidikan. Jakarta : Rajawali

Toeti, S. 1994. Teori dan Model Pembelajaran. Jakarta : DEPDIKBUD

Wibawa,A.2003. Pendekatan Penelitian Tindakan Kelas. Jakarta: Gramedia

Winkel, W.S. 1996. Psikologi Pengajaran. Jakarta : Grasindo 